\title{
Correlation and Heterosis Studies in various Populations of Indian Mustard (Brassica juncea L. Czern \& Coss)
}

\author{
Madhu Aggarwal ${ }^{1}$, M.S. Punia ${ }^{1}$ and Monika ${ }^{2} *$ \\ ${ }^{1}$ Department of Genetics \& Plant Breeding, ${ }^{2}$ Department of Molecular Biology, \\ Biotechnology \& Bioinformatics, CCS Haryana Agricultural University, \\ Hisar 125004, India \\ *Corresponding author
}

A B S T R A C T

Keywords

Brassica juncea, Phenotypic correlations, Heterosis, correlation Coefficient and Quantitative traits

Article Info

Accepted:

18 February 2019 Available Online: 10 March 2019
The present study was carried out with six crosses viz. Varuna x Bio-YSR, Rohini x BioYSR, RH-8812 x Bio-YSR, Varuna x JMMWR-9348, Rohini x JMMWR-9348 and RH$8812 \times$ JMMWR-9348 with their six generations viz. $\mathrm{P}_{1}, \mathrm{P}_{2}, \mathrm{~F}_{1}, \mathrm{~F}_{2}, \mathrm{BC}_{1}$ and $\mathrm{BC}_{2}$. Considerable amount of variation was envisaged among parents and their different generations for various morphological traits and yield related studies. Seed yield per plant showed significant positive correlation with number of primary branches per plant $(0.319)$, number of secondary branches per plant $(0.275)$, main shoot length $(0.347)$, number of siliqua on main shoot $(0.405)$, siliqua length $(0.213)$, seeds per siliqua $(0.268), 1000$ seed weight (0.203) and oil content (0.319). Heterosis was found significant for the characters like days to flowering, days to maturity, plant height, main shoot length, number of siliquae on main shoot and seeds per siliqua. 7 out of 33 hybrids showed positive and significant heterosis over mid parent, better parent and checks for seed yield per plant. Study of correlation between different agronomic traits can provide a good means to improve yield in Brassica.

\section{Introduction}

Indian mustard (Brassica juncea L. Czern \& Coss.) is the major oilseed crop of India ranking first both in acreage and production of rapeseed and mustard in Asia. Four species of Brassica viz. Brassica napus, Brassica campestris, Brassica juncea and Brassica carinata are grown world wide as a source of edible oil. Brassica juncea commonly known as Indian mustard is being grown mainly as a source of vegetable oil and condiment. Its oil content varies between 28.6 to 45.7 per cent. In addition to edible purposes, it is also used as hair oil and lubricant. Mustard cake (seed residue) is used as cattle feed and in fertilizers. Indian mustard (Brassica juncea) is a naturally self pollinated species, but frequent out crossing occurs in this crop which varies from 5 to 30 per cent depending upon the environmental conditions and pollinating insect population. B. juncea commonly called 
as Indian mustard, contributes more than $80 \%$ to the total rapeseed-mustard production in the country and is an important component in the oilseed sector. In spite of many beneficial uses, it received adequate attention for genetic improvement and management only after the inception of technological mission in oilseeds 1986 and country became almost self reliant in edible oil. But the requirement of edible oil is increasing at the rate of 3-4 per cent annually due to ever increasing population and improved standard of living. In India, Brassica juncea occupies second largest area after groundnut with 6.32 million hectares of area under cultivation producing about 7.9 million tones of seed annually, with $17 \%$ increase in production (Anonymous, 2017). Improvement through breeding depends upon the amount of genetic variability available in the gene pool. Further past experiences in mustard breeding indicated that there is an immense scope in enhancing seed yield to new level by reshuffling the genes through hybridization of suitable parents. It is a well known fact that greater the variability among the parents, greater is the chances of further improvement. The crosses involving diverse parents are expected to greater considerable amount of genetic variability improvement and exploitation of mustard. Seed yield is a complex character and a resultant of several morphological interactions. The profitable use of different morphological traits largely depends upon their association with seed yield and also on the nature of relationship among themselves. The manifestation of increased size, vigor of development, more productivity and similar beneficial effects have long been recognized in many first generation hybrids of plants. The increase in size and vigor resulting from hybridization has been designated variously as the stimulating effect of hybridity, heterosis or hybrid vigor. Heterosis is more commonly found in cross-pollinated crops because they are heterozygous in nature and their floral structure also facilitates the hybridization. Heterosis has also been found in self-pollinated crops although its exploitation is at lesser extent because its floral structure discourages easy crossing for hybrid production.

Knowledge of the genotypic and phenotypic correlation for quantitative characters is useful in the formulation of efficient breeding programme towards tailoring and utilizing efficient plant type (Baker, 1990). Therefore, the present investigation helps to study correlation and heterosis for suggesting a suitable selection procedure based on the results achieved for the improvement of Brassica.

\section{Materials and Methods}

Six crosses namely RH-8812 x Bio-YSR (S x R), RH-8812 x JMMWR-9348 (S x R), Varuna $x$ Bio-YSR ( $S \quad x \quad R)$, Varuna $x$ JMMWR-9348 (S x R), Rohini x Bio-YSR (S $\mathrm{X}$ R) and Rohini x JMMWR-9348 (S x R) were made. These crosses were designated as C-I, C-II, C-III, C-IV, C-V and C-VI, respectively. The $\mathrm{F}_{1}$ hybrids and parents were raised during Rabi 2012- 2013. Each $F_{1}$ was selfed in order to obtain $F_{2}$ generation and simultaneously back crossed with each of the parents to produce back cross generations $\mathrm{BC}_{1}$ and $\mathrm{BC}_{2}$, respectively. Fresh crosses between the parents were also attempted to obtain $F_{1}$ seed. Thus, the experimental material finally comprised of six generations i.e. parents $\left(\mathrm{P}_{1}\right.$ and $\left.\mathrm{P}_{2}\right), \mathrm{F}_{1}, \mathrm{~F}_{2}$ and back crosses $\left(\mathrm{BC}_{1}\right.$ and $\mathrm{BC}_{2}$ ) of six crosses grown in a Randomized Block Design. There were two rows of nonsegregating generations $\left(\mathrm{P}_{1}, \mathrm{P}_{2}\right.$ and $\left.\mathrm{F}_{1}\right), 6$ rows of $\mathrm{F}_{2}$, and 3 rows of each $\mathrm{BC}_{1}$ and generations. Randomly selected plants from each row of non-segregating generations and 12 plants from $F_{2}$ generation and 5 plants from both backcrosses were chosen and five plants were randomly selected for parents and their $F_{1}$ 's for recording observations on the various 
phenotypic traits. 49 genotypes consisting of 11 parental lines, 3 testers and $33 \mathrm{~F}_{1}$ crosses along with 2 standard checks (RH-0749 and RH-8113) of Indian mustard were used for heterosis and correlation analysis. In the present study, heterosis on mid parent, better parent (heterobeltiosis) as well as over standard check (economic heterosis) was worked out for twelve characters. Phenological traits influencing yield including days to flower initiation, maturity duration, plant height, number of primary branches per plant, number of secondary branches per plant, main shoot length, number of siliquae on main shoot, siliqua length, number of seeds per siliquae, 1000-seed weight, seed yield per plant and oil content were taken in parents, backcrosses, $F_{1}$ and $F_{2}$ generation of Brassica juncea for evaluation of genetic variability and correlation.

\section{Statistical analysis}

Statistical analysis was done using OPSTAT software by using the phenotypic data recorded from along with parents. The mean and range values for each character were calculated. Phenotypic correlation coefficients for all possible pairs of characters were calculated and tested against standardized tabulated significant value of $r$ with $(n-2)$ degree of freedom as per the procedure given by Fisher and Yates (1963). The percent increase (+) or decrease (-) of $F_{1}$ cross average over mid parent was calculated to observe heterotic effects for all the traits. The estimates of heterosis over the mid parent were calculated using the standard formula.

\section{Results and Discussion}

\section{Correlation coefficient analysis in various phenological traits of Brassica juncea}

Seed yield per plant was found to be positively and significantly correlated with number of primary branches per plant, number of secondary branches per plant, main shoot length, siliquae on main shoot, siliqua length, number of seeds per siliqua, 1000 seed weight and oil content whereas it was negative and non significant for days to flowering, days to maturity and plant height. Days to flowering showed positive and significant correlations for days to maturity, number of secondary branches per plant, main shoot length, and number of siliquae on main shoot, 1000 seed weight and negative significant correlation for oil content. Days to maturity showed positive and significant correlations for days to flowering, plant height, 1000 seed weight and oil content whereas negative and significant correlation was observed for number of siliquae on main shoot, siliqua length and seeds per siliqua. Plant height showed positive correlation with days to maturity but negative and significant correlation for number of primary branches per plant and oil content while for other traits it was non-significant (Table 1).

Number of primary branches per plant showed positive and significant correlations for main shoot length and number of siliquae on main shoot. Number of secondary branches per plant showed positive and significant correlation for days to flowering and oil content, whereas, it was negative and significant for main shoot length, length and seeds per siliqua.

Main shoot length showed positive and significant correlations for days to flowering, number of primary branches per plant, number of siliquae on main shoot, siliqua length, seeds per siliqua, 1000 seed weight, whereas, negative and significant for oil content. Number of siliquae on main shoot showed positive and significant correlations for days to flowering, number of primary branches per plant, siliqua length, seeds per siliqua whereas negative and significant for 1000 seed weight 
and oil content. Siliqua length showed positive and significant correlations for main shoot length, number of siliquae on main shoot, seeds per siliqua, 1000 seed weight and negative and significant for oil content. Seeds per siliqua showed positive and significant correlation for main shoot length, number of siliquae on main shoot, siliqua length and 1000 seed weight. 1000 seed weight showed positive and significant correlation for days to flowering, days to maturity, main shoot length, siliqua length and seeds per siliqua. Oil content showed positive and significant correlation for days to maturity and number of secondary branches per plant.

Seed yield per plant was found to be positively and significantly correlated with number of primary branches per plant, number of secondary branches per plant, main shoot length, siliquae on main shoot, siliqua length, number of seeds per siliqua, 1000 seed weight and oil content whereas it was negative and non significant for days to flowering, days to maturity and plant height (Table 1). The results show confirmity with those of Shalini et al., (2000); Sinha et al., (2001) and Bind et al., (2014).

Srivastava and Singh (2002) observed positive significant correlation of seed yield with number of secondary branches. Days to flowering showed positive and significant correlations for days to maturity, number of secondary branches per plant, main shoot length, siliquae on main shoot and 1000 seed weight which are also in line with those reported by Hasan et al., (2015). Plant height exhibited negative association with seeds per siliqua which was also reported by Kardam and Singh (2005), whereas, it showed positive correlation with days to maturity but negative and significant correlation for number of primary branches per plant and oil content while for other traits it was non-significant which was contrary to the results observed for plant height with length of siliqua (Basalma, 2008), plant height with length of raceme (Sadat et al., 2010) and plant height with number of seeds per siliqua (Azadgoleh et al., 2009). Plant height showed negative association with seed yield per plant which was in accordance with the finding of Labana et al., (1980).

Main shoot length showed positive and significant correlations for days to flowering, number of primary branches per plant, number of siliquae on main shoot, siliqua length, number of seeds per siliqua, 1000 seed weight. Similar association was reported by Chowdhury et al., (2007) for positive and significant association of main shoot length with siliqua length. Number of siliquae on main shoot showed positive and significant correlations for days to flowering, number of primary branches per plant, siliqua length, seeds per siliqua whereas negative and significant for 1000 seed weight and oil content. This is in conformity of the findings of Kardam and Singh (2005).

$\mathrm{Xu}$ and Yao (2006) studied the inheritance of siliqua length among several lines of B. napus and observed that lines with the longest siliqua generally showed significantly higher correlation with seed yield. Seeds per siliqua showed positive and significant correlation for main shoot length, number of siliquae on main shoot, siliqua length and 1000 seed weight. Similar results were reported by Hasan et al., (2015) for the positive association of seeds per siliqua and siliqua length.

1000 seed weight showed positive and significant correlation for days to flowering, days to maturity, main shoot length, siliqua length and seeds per siliqua. This is in conformity with the findings of Srivastava and Singh (2002). In contrast, Sandhu and Gupta (1996) reported that days to $50 \%$ flowering and 1000-seed weight exhibited negative 
correlation with seed yield. Siliqua length showed positive and significant correlations for main shoot length, number of siliquae on main shoot, seeds per siliqua, 1000 seed weight and negative and significant for oil content which was in accordance with Yadava et al., (2011).

In our study, characters which exhibited positive association with seed yield per plant also exhibited positive association among themselves. Thus, these characters could be simultaneously improved to increase the seed yield. Singh et al., (1985) and Pal and Singh (1986) reported considerable variability for days to flowering, days to maturity, plant height, number of primary, secondary and tertiary branches, number of seeds per siliqua, siliqua length, 1000- seed weight, biological yield, seed yield and harvest index in the non segregating generations of four crosses.

Singh et al., (2013) observed variability for agronomic traits viz. plant height $(\mathrm{cm})$, main shoot length $(\mathrm{cm})$, days to flower initiation, number of siliquae on main raceme, number of seeds per siliqua, seed yield per plot (g), biological yield per plot (g), harvest index $(\%)$, days to maturity and 1000 seed weight (g). Our agronomic traits also showed variability showing that genetic material is perfect for diversity and variability analysis.

Raliya et al., (2018) observed phenotypic coefficient of variation higher than the genotypic coefficient of variation for all the characters under study. Seed yield per hectare was found to be positively correlated with 1000-seed weight, siliqua length, plant height, main shoot length and days to maturity at genotypic level. Our study also shows similar results with positive correlation of yield with 1000 seed weight, siliqua length and main shoot length. Iqbal et al., (2014) found a significant correlation of plant height, number of seeds/siliqua, number of siliqua/plant and length of siliqua with seed yield /plant in Brassica species which are in agreement with our results.

Seed yield per plant in mustard was found to be positively and significantly correlated with pod length, number of seeds per pod and oil content while, negative significant association of seed yield was observed with days to first flowering and total biomass (Roy et al., 2016). Our studies also showed positive correlation of no. of seeds/siliqua with seed yield/plant.

Yadava (1983); Gupta and Kumar (1984); Singh et al., (1985) and Pal and Singh (1986) reported considerable variability for days to flowering, days to maturity, plant height, number of primary, secondary and tertiary node, number of seeds per siliqua, siliqua length, 1000- seed weight, biological yield, seed yield and harvest index in the non segregating generations of four crosses. Our population and crosses also showed huge variations among the various traits under study.

\section{Heterosis analysis}

Heterosis was found significant for the characters like days to flowering, days to maturity, plant height, main shoot length, number of siliquae on main shoot and seeds per siliqua whereas for the characters like number of primary branches per plant, number of secondary branches per plant, 1000 seed weight, seed yield per plant and oil content only few hybrids showed significant heterosis. 7 out of 33 hybrids showed positive and significant heterosis over mid parent, better parent and checks for seed yield per plant. Different cross combinations exhibited the maximum value of better and mid-parent heterosis for the remaining traits, viz. days to maturity, number of secondary branches per plant, plant height and 1000-seed weight. 
Table.1 Genotypic correlation coefficient among twelve characters of Indian mustard

\begin{tabular}{|c|c|c|c|c|c|c|c|c|c|c|c|c|}
\hline Characters & $\begin{array}{l}\text { Days to } \\
\text { flowering }\end{array}$ & $\begin{array}{l}\text { Days to } \\
\text { maturity }\end{array}$ & $\begin{array}{c}\text { Plant } \\
\text { height } \\
\text { (cm) }\end{array}$ & $\begin{array}{l}\text { Number } \\
\text { of } \\
\text { primary } \\
\text { branches } \\
\text { / plant }\end{array}$ & $\begin{array}{c}\text { Number of } \\
\text { secondary } \\
\text { branches / } \\
\text { plant }\end{array}$ & $\begin{array}{l}\text { Main } \\
\text { shoot } \\
\text { length } \\
\text { (cm) }\end{array}$ & $\begin{array}{l}\text { Number } \\
\text { of } \\
\text { siliquae } \\
\text { on main } \\
\text { shoot }\end{array}$ & $\begin{array}{c}\text { Siliqua } \\
\text { length } \\
\text { (cm) }\end{array}$ & $\begin{array}{c}\text { Seeds } \\
/ \\
\text { siliqua }\end{array}$ & $\begin{array}{c}1000 \\
\text { seed } \\
\text { weight } \\
\text { (g) }\end{array}$ & $\begin{array}{c}\text { Oil } \\
\text { content } \\
(\%)\end{array}$ & $\begin{array}{c}\text { Seed } \\
\text { yield/ } \\
\text { plant } \\
(g)\end{array}$ \\
\hline \multicolumn{13}{|l|}{ Days to flowering } \\
\hline Days to maturity & $0.573^{* *}$ & & & & & & & & & & & \\
\hline Plant height (cm) & 0.086 & $0.851^{* *}$ & & & & & & & & & & \\
\hline $\begin{array}{l}\text { Number of primary } \\
\text { branches / plant }\end{array}$ & -0.005 & -0.058 & $0.220^{* *}$ & & & & & & & & & \\
\hline $\begin{array}{l}\text { Number of secondary } \\
\text { branches / plant }\end{array}$ & $0.204^{*}$ & -0.069 & 0.092 & 0.081 & & & & & & & & \\
\hline Main shoot length $(\mathrm{cm})$ & $0.185^{*}$ & 0.132 & -0.005 & $0.261^{* *}$ & $-0.449^{* *}$ & & & & & & & \\
\hline $\begin{array}{l}\text { Number of siliquae on } \\
\text { main shoot }\end{array}$ & $0.168^{*}$ & $-0.180^{*}$ & -0.056 & $0.398^{* *}$ & -0.140 & $0.777^{* *}$ & & & & & & \\
\hline Siliqua length $(\mathrm{cm})$ & 0.074 & $-0.523^{* *}$ & -0.124 & 0.036 & $-0.465^{* *}$ & $0.629^{* *}$ & $0.367^{* *}$ & & & & & \\
\hline Seeds / siliqua & 0.032 & $-0.474^{* *}$ & -0.100 & 0.003 & $-0.530^{* *}$ & $0.571^{* *}$ & $0.325^{* *}$ & $0.990^{* *}$ & & & & \\
\hline 1000 seed weight (g) & $0.753^{* *}$ & $0.188^{*}$ & -0.013 & 0.028 & 0.002 & $0.206^{*}$ & $-0.197^{*}$ & $0.439^{* *}$ & $0.283^{* *}$ & & & \\
\hline Oil content $(\%)$ & $-0.306^{* *}$ & $0.357^{* *}$ & $0.189^{*}$ & -0.079 & $0.383^{* *}$ & $0.616^{* *}$ & $-0.240^{* *}$ & $0.540^{* *}$ & $0.245^{* *}$ & $0.437^{* *}$ & & \\
\hline Seed yield/ plant (g) & -0.151 & -0.020 & -0.040 & $0.319^{* *}$ & $0.275^{* *}$ & $0.347^{* *}$ & $0.405^{* *}$ & $0.213^{* *}$ & $0.268^{* *}$ & $0.203^{*}$ & $0.335^{* *}$ & \\
\hline
\end{tabular}

*, **- significant by the $\mathrm{f}$-test at the $5 \%$ and $1 \%$ probability level, respectively

Table.2 Heterosis in percentage for seed yield per plant (g) and oil content (\%)

\begin{tabular}{|c|c|c|c|c|c|c|c|c|c|}
\hline \multicolumn{6}{|c|}{ Seed yield per plant (g) } & \multicolumn{4}{|c|}{ Oil content $(\%)$} \\
\hline \multirow{2}{*}{$\begin{array}{l}\text { S. } \\
\text { No. }\end{array}$} & \multirow[t]{2}{*}{ Hybrid } & \multirow[t]{2}{*}{ Mid-parent } & \multirow[t]{2}{*}{ Better parent } & \multicolumn{2}{|c|}{ Over standard checks } & \multirow[t]{2}{*}{ Mid-parent } & \multirow[t]{2}{*}{ Better parent } & \multicolumn{2}{|c|}{ Over standard checks } \\
\hline & & & & $\begin{array}{c}\text { Check1 } \\
\text { (RH-0749) }\end{array}$ & $\begin{array}{c}\text { Check2 } \\
\text { (RH-8113) }\end{array}$ & & & $\begin{array}{c}\text { Check1 } \\
\text { (RH-0749) }\end{array}$ & $\begin{array}{c}\text { Check2 } \\
\text { (RH-8113) }\end{array}$ \\
\hline 1 & RH-0845 x Bio-YSR & 0.40 & -0.47 & $-2.85^{*}$ & $-6.77 *$ & 0.00 & -0.27 & $-0.69 *$ & $-1.62 *$ \\
\hline 2 & RH-0845 x JM-1 & $-3.70 *$ & $-4.13^{*}$ & $-15.47 *$ & $-18.88 *$ & -0.35 & $-0.77 *$ & $-1.21 *$ & $-2.13 *$ \\
\hline 3 & RH-0845 x JMMWR-9348 & -0.93 & $-3.13 *$ & $-14.87 *$ & $-18.30 *$ & 0.42 & 0.10 & 0.52 & -0.43 \\
\hline 4 & RH-0860 x Bio-YSR & 4.03* & $2.87 *$ & $4.35 *$ & 0.14 & 0.00 & -0.20 & -0.52 & $-1.45^{*}$ \\
\hline
\end{tabular}




\begin{tabular}{|c|c|c|c|c|c|c|c|c|c|}
\hline 5 & RH-0860 x JM-1 & $3.20 *$ & 0.73 & $6.46^{*}$ & 2.16 & 0.08 & -0.27 & 0.09 & $-0.85^{*}$ \\
\hline 6 & RH-0860 x JMMWR-9348 & $5.87 *$ & $5.70 *$ & $6.61 *$ & $2.31 *$ & 0.28 & 0.03 & 0.34 & -0.60 \\
\hline 7 & RH-1120 x Bio-YSR & 1.93 & 0.47 & $6.76^{*}$ & $2.45^{*}$ & 0.23 & 0.17 & $\mathbf{0 . 7 8 *}$ & -0.17 \\
\hline 8 & RH-1120 x JM-1 & 1.27 & 1.10 & $9.61^{*}$ & $5.19 *$ & -0.22 & -0.30 & 0.00 & $-0.94 *$ \\
\hline 9 & RH-1120 x JMMWR-9348 & 0.47 & $-2.33^{*}$ & $-5.86 *$ & $-9.65 *$ & $-0.75 *$ & $-0.77^{*}$ & $-1.64 *$ & $-2.56 *$ \\
\hline 10 & RH-1126 x Bio-YSR & $5.88 *$ & $3.43 *$ & $6.91 *$ & $2.59 *$ & -0.08 & -0.20 & -0.52 & $-1.45 *$ \\
\hline 11 & RH-1126 x JM-1 & $3.62 *$ & -1.03 & $2.55^{*}$ & -1.59 & -0.33 & $-0.60 *$ & $-0.78 *$ & $-1.71^{*}$ \\
\hline 12 & RH-1126 x JMMWR-9348 & $6.05^{*}$ & $4.93 *$ & 1.65 & $-2.45^{*}$ & 0.07 & -0.10 & 0.00 & $-0.94 *$ \\
\hline 13 & RH-1139 x Bio-YSR & -1.67 & $-3.20 *$ & $-22.97 *$ & $-26.08 *$ & 0.05 & -0.10 & 0.52 & -0.43 \\
\hline 14 & RH-1139 x JM-1 & 2.10 & -0.73 & -0.15 & $-4.18 *$ & 0.07 & 0.07 & $0.95 *$ & 0.00 \\
\hline 15 & RH-1139 x JMMWR-9348 & $5.70 *$ & $5.50 *$ & $4.20 *$ & 0.00 & -0.13 & -0.23 & 0.17 & $-0.77 *$ \\
\hline 16 & RH-1152 x Bio-YSR & 0.52 & -0.80 & $-12.16^{*}$ & $-15.71 *$ & -0.22 & -0.43 & $-1.12 *$ & $-2.05 *$ \\
\hline 17 & RH-1152 x JM-1 & $3.25 *$ & 0.63 & $6.01 *$ & 1.73 & -0.57 & $-0.93 *$ & $-1.64 *$ & $-2.56 *$ \\
\hline 18 & RH-1152 x JMMWR-9348 & 1.12 & 1.10 & $-15.47 *$ & $-18.88 *$ & -0.43 & $-0.70 *$ & $-1.55 *$ & $-2.47 *$ \\
\hline 19 & RH-1155 x Bio-YSR & $3.48^{*}$ & 1.13 & $-3.45^{*}$ & $-7.35^{*}$ & -0.27 & -0.47 & $-1.21 *$ & $-2.13 *$ \\
\hline 20 & RH-1155 x JM-1 & $5.88 *$ & $2.23 *$ & 13.21* & $8.65^{*}$ & -0.38 & $-0.73 *$ & $-1.12 *$ & $-2.05 *$ \\
\hline 21 & RH-1155 x JMMWR-9348 & 2.05 & 1.03 & $-15.92 *$ & $-19.31 *$ & $-0.72 *$ & $-0.97 *$ & $-2.24 *$ & $-3.15 *$ \\
\hline 22 & RH-8812 x Bio-YSR & 1.93 & 1.93 & 0.15 & $-3.89 *$ & -0.35 & -0.37 & $-0.95 *$ & $-1.88 *$ \\
\hline 23 & RH-8812 x JM-1 & 1.30 & 0.00 & $3.15^{*}$ & -1.01 & -0.43 & $-0.60 *$ & $-0.78 *$ & -1.701 \\
\hline 24 & RH-8812 x JMMWR-9348 & -1.03 & $-2.37 *$ & $-19.22 *$ & $-22.48 *$ & -0.50 & -0.57 & $-1.21 *$ & $-2.13 *$ \\
\hline 25 & Rohini x Bio-YSR & $-3.72 *$ & $-4.97 *$ & $-19.67 *$ & $-22.91 *$ & -0.53 & $-0.63 *$ & $-1.64 *$ & $-2.56 *$ \\
\hline 26 & Rohini x JM-1 & $-4.98 *$ & $-5.03 *$ & $-19.52 *$ & $-22.77 *$ & 0.35 & 0.10 & $1.03 *$ & 0.09 \\
\hline 27 & Rohini x JMMWR-9348 & $-3.05^{*}$ & $-5.63 *$ & $-22.67 *$ & $-25.79 *$ & -0.18 & -0.33 & $-0.60 *$ & $-1.54 *$ \\
\hline 28 & Kranti x Bio-YSR & -1.28 & $-2.77 *$ & $-21.02 *$ & $-24.21 *$ & -0.28 & -0.37 & -0.52 & $-1.45 *$ \\
\hline 29 & Kranti x JM-1 & -1.75 & $-4.53 *$ & $-17.27 *$ & $-20.61 *$ & $-0.70 *$ & $-0.77^{*}$ & $-1.21 *$ & $-2.13 *$ \\
\hline 30 & Kranti x JMMWR-9348 & 7.95* & 7.80* & $14.57^{*}$ & 9.94* & -0.33 & -0.37 & -0.52 & $-1.45 *$ \\
\hline 31 & Varuna x Bio-YSR & $5.77 *$ & $3.70 *$ & 8.11* & $3.75^{*}$ & -0.25 & -0.43 & $-1.12 *$ & $-2.05 *$ \\
\hline 32 & Varuna x JM-1 & $4.17 *$ & 0.80 & $6.76^{*}$ & $2.45^{*}$ & -0.03 & -0.37 & $-2.24 *$ & $-1.11 *$ \\
\hline \multirow[t]{2}{*}{33} & Varuna x JMMWR-9348 & $5.73 *$ & $5.00 *$ & 1.95 & -2.16 & 0.43 & 0.20 & 0.78* & -0.17 \\
\hline & SE $( \pm)$ & 1.20 & & & & 0.32 & & & \\
\hline
\end{tabular}

* Significant at 5\% level 
Moderate heterosis was observed for seed yield per plant, seeds per siliqua, and number of primary branches per plant whereas, it was low for other characters (Table 2). Aher et al., (2009) observed moderate heterosis for seed yield per plant, number of siliqua per plant and number of secondary branches per plant, whereas, in the remaining character low amount of heterosis was reported. The highest standard heterosis for seed yield was observed in RSK-87 x GM-2 (42.95\%) followed by SKM-95-85 x GM-2 (40.11\%) and RSK-87 x Varuna (37.67\%). Patel et al., (2012) reported on the basis of mean values, the hybrid RK 9501 x GM 2 and the parent RK 9501 were having most outstanding performance for seed yield per plant. A considerable degree of desirable and significant heterosis over mid parent (MP) and better parent (BP) was noted for crosses GM 1 x GM 3 and GM 3 x SKM 139 respectively for seed yield per plant.

In conclusion, the present study envisaged considerable amount of variation among parents and their different generations for various morphological traits. Seed yield per plant showed significant positive correlation with number of primary branches per plant, number of secondary branches per plant, main shoot length, number of siliqua on main shoot, siliqua length, seeds per siliqua, 1000 seed weight and oil content. Significant heterosis for was observed for plant height, main shoot length, number of siliquae on main shoot, siliqua length, days to flowering, days to maturity and seed yield per plant. However, the magnitude and direction of heterosis was varying from cross to cross. Correlation and heterosis data among the crosses can be used for improving yield and phenological traits in Brassica.

\section{References}

Aher, C.D., Shelke, L.T., Chinchane, V.N., Borgaonkar, S.B. and Gaikwad, A.R. 2009. Heterosis for yield and yield components in Indian mustard [Brassica juncea (L.) Czern and Coss]. Int. J. Plant Sci. 4 (1): 30-32.

Anonymous, 2017. Directorate of Economics and Statistics, Department of Agriculture and Cooperation, Ministry of Agriculture, Government of India. $4^{\text {th }}$ Advance Estimates released as on 17.08.2017.

Azadgoleh, E.M.A., Zamami, M. and Yasari, E. 2009. Agronomical important traits correlation in rapeseed (Brassica napus L.) genotypes. Res. J. Agric. Biol. Sci. 5 (5): 798-802.

Baker, R.J. (1990). Agronomic performance of semi-dwarf and normal height spring wheat seeded at different dates. Can. J. Pl. Sci. 70: 295-298.

Basalma, D. 2008. The correlation and path analysis of yield and yield components of different winter rapeseed (Brassica napus spp. Oleifera L.) cultivars. Res. J. Agric. and Biol. Sci. 4 (2): 120-125.

Bind, D., Singh, D. and Dwivedi, V.K. 2014. Genetic variability and character association in Indian mustard [Brassica juncea (L.) Czern \& Coss]. Agric. Sci. Digest. 34 (3): 183 - 188.

Chowdhury, N., Javidfar, F., Elmira, J.Y. and Mirza, M.Y. 2007. Relationship among yield components and selection criteria for yield improvement in winter rapeseed (Brassica napus L.). In: Oilseed Research Program, National Agricultural Research Centre, Islamabad, Pakistan. 35 (2): 16717.

Fisher, R.A. and Yates, F. 1963. Statistical tables for biological, agricultural and medicinal research. (6th ed) Oliver and Boyd. Edinburgh. pp, 63.

Hasan, E.U., Bibi, T., Mustafa, H.S.B., Mahmood, T., Kalyar, M.T.A. and Salim, J. 2015. Genetic evaluation and characterization for yield and related traits in mustard (Brassica juncea). Res $J$. Agri and Envi. Manag. 4 (2): 082-087.

Iqbal, M.S., Haque, M.S., Nath, U.K. and Hamim, I. 2014. Genetic diversity analysis of mustard germplasm based on phenotypic traits for selection of short 
duration genotypes. Int Journal of Agricultural Science Research 3: 141156.

Kardam, D.K. and Singh, V.V. 2005. Correlation and path analysis in Indian mustard [Brassica juncea (L.) Czern \& Coss.] grown under rainfed condition. $J$. Spices \& Arom. Crops. 14 (1): 56-60.

Labana, K.S., Chaurasia, B.D. and Sangha, A.S. 1980. Genetic variability and inter character associations in the mutants of Indian mustard. Ind. J. Agric. Sci. 50: 803-806.

Pal, Y. and Singh, H. 1986. Genetic effects for days to flowering, maturity and seed yield in Indian mustard under two environments. J. Oilseeds Res. 3: 210215.

Patel, A. M., Prajapati, D. B. and Patel, D. G. 2012. Heterosis and combining ability studies in Indian mustard (Brassica juncea L.). Ind. J. Sci. Res. Tech. 1 (1): 38-40.

Raliya, B., Kumar, K.R., Pukhraj, Jat, R., Meena, H.S. and Mundariya, R. 2018. Genetic Variability and Character Association in Indian Mustard (Brassica juncea L.). Int Journal of Agriculture Sciences, 10(9): 5993-5996.

Roy, R.K., Kumar, A., Kumar, S. and Kumar, A. 2016. Genetic variability, correlation, path analysis and genetic diversity studies in late sown mustard (Brassica juncea L. Czern \& Coss.). The Bioscan 11(4):31173124.

Sadat, H.A., Nematzadeh, G.A., Jelodar, N.B. and Chapi, O.G. 2010. Genetic evaluation of yield and yield components at advanced generations in rapeseed $(B$. napus L.). Afr. J. Agric. Res. 5 (15): 1958- 1964.

Sandhu, S.K. and Gupta, N.P. 1996. Genetic divergence and correlation studies in Brassica species. Crop Improv. 23 (2): 253-256.

Shalini, T. S., Sheriff, R. A., Kulkarni, R. S. and Venkataramana, P. 2000. Variability studies in Indian mustard [Brassica juncea (L.) Czern \& Coss]. Res. Crops. 1 (2): 230-234. Singh, K.K., Singh, R., Singh, J.N. and Singh, D. 2013. Gene effect studies for earliness and seed yield in Indian mustard [Brassica juncea (L.) Czern \& Coss.]. Ann. Agric. Res. 34 (1): 86-90.

Sinha, P., Singh, S.P. and Pandey, I.D. 2001. Character association and path analysis in Brassica species. Ind. J. Agric. Res. 35 (1): 63.65. Singh, M. and Singh, G. 1997. Correlation and path analysis in Indian mustard (Brassica juncea L.) under mid hills of Sikkim. J. Hill Res. 10 (1): 10-12.

$\mathrm{Xu}$, S.Q. and Yao, X. 2006. Study on the correlation between yield characters and yield of superior rape (Brassica napus L.) in north Zhejiang Province. Acad. Agric Sci. 22 (2): 65-67.

Yadava, D.K., Giri, S.C., Vignesh, M., Vasudev, S., Yadav, A.K., Dass, B.; Singh, R., Singh, N., Mohapatra, T. and Prabhu, K.V. 2011. Genetic variability and trait association studies in Indian mustard (Brassica juncea). Ind. J. Agric. Sci. 81 (8): 712-716.

\section{How to cite this article:}

Madhu Aggarwal, M.S. Punia and Monika. 2019. Correlation and Heterosis Studies in various Populations of Indian Mustard (Brassica juncea L. Czern \& Coss). Int.J.Curr.Microbiol.App.Sci. 8(03): 2122-2130. doi: https://doi.org/10.20546/ijcmas.2019.803.254 